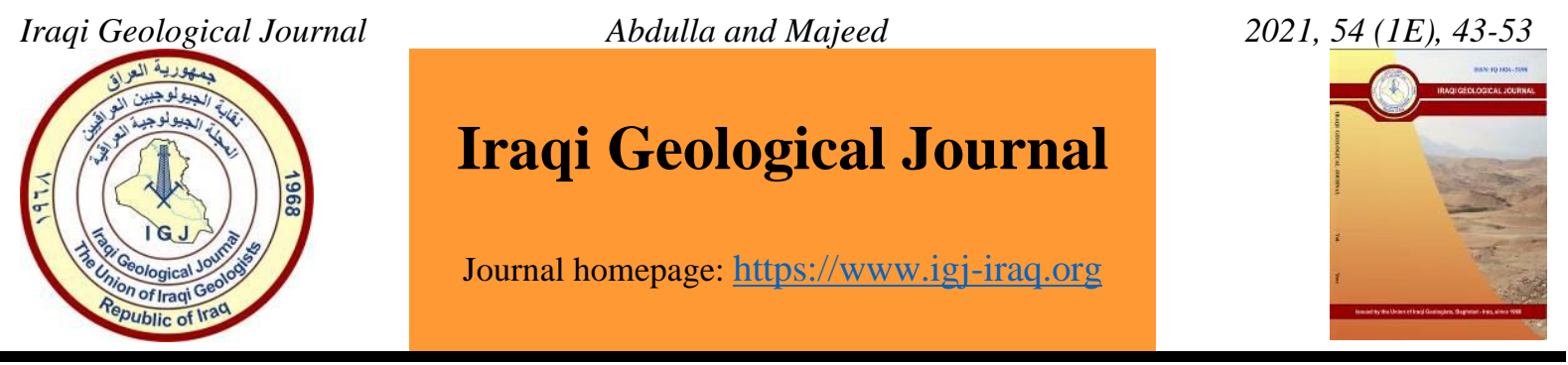

\title{
Enhancing Engineering Properties of Expansive Soil Using Marble Waste Powder
}

\author{
Rozan Abdulla ${ }^{1}$ and Nadhmiah Majeed ${ }^{2, *}$ \\ ${ }^{1}$ Department of Geology, College of Science, Sulymania University, Erbil, Iraq \\ ${ }^{2}$ Department of Geology, College of Science, Salahaddin University, Erbil, Iraq \\ * Correspondence: nadhmianajm@yahoo.com
}

Received: 1 January 2021; Accepted: 25 March 2021; Published: 31 May 2021

\begin{abstract}
Owing to its propensity to swell when in contact with water, expansive soil causes severe structural problems and shrinks when they dry out. Soil stabilization is a well-known method used to enhance the soil's physical and engineering properties and is commonly adopted for improving soil structures. The mechanical stabilization of different soils is evaluated by adding varying proportions of marble dust (10, 20, 30 percent) of Penjwen, Said Sadiq and Pirmam marble waste powder) to expansive soil. Shear strength and consolidation parameters, such as void ratio, compression index, and sample swelling index, were determined as basic properties. The marble dust is obtained from the cutting and grinding of real marble from the Erbil marble factory in the experimental program. The addition of marble dust decreases the swelling percentage, with an increase in the percentage of marble powder in swelling soils. It is concluded that the swelling in Bastora soil is more than that of Erbil Airport soil, based on the swelling index studies.
\end{abstract}

Keywords: Expansive soil; Marble waste powder; Direct shear strength; Consolidation; Swelling soil

\section{Introduction}

The swelling in expansive soil is a present significant geotechnical and structural engineering challenges. This is a worldwide problem which presents different facets in different parts of the world. The most widely distributed and costly of geologic hazards may be considered to be one of the foundations and engineering problems and still facing because of the potential danger of unpredictable upward movements of different structures founded on such soil. Of various soil stabilization techniques, mechanical stabilization by marble waste powder (MWP) is relatively simple and most economical in most situations and prevents the environment from pollution. In the arid and semi-arid regions of the world, swelling soil deposits occur. (Mishra et al. 2008). The presence of montmorillonite in the soil increased in its swell capacity since its volume swells as it absorbs the water (Chen, 1988; Nelson and Miller, 1992). Changes in volume in expansive soils cause foundation instability and damage to loaded structures such as railroads, road pavements, retaining walls, road sidewalks and liners for reservoirs. (Zumrawi et al. 2016.). Several percent of lime additives used by Pastor et al. (2019) demonstrate a decrease in their deformability and an improvement in the strength of the expansive soil. Treatment of soil specimens with different percentages of Poly Vinyl Acetate. These treated specimens were tested

DOI: 10.46717 /igj.54.1E.4Ms-2021-05-25 
for compaction properties, unconfined compression strength properties, free swell and Atterberg limits. Poly vinyl acetate was found to have a major effect on the properties of the treated soil (Zumrawi, 2019). Mixing silica smoke with cement matrix expands the creation of new cement compounds and offers denser microstructure that prevents expansionary clay problems (Goodarzi et al. 2016). In general, little quantities of Portland cement are stabilized to improve the strength and durability of rammed soil, but the alternative solution is to use lime to stabilize the raw soil in road construction (Ciancio et al., 2013). The stabilization of expansive soil is a very important modification to determine geotechnical properties. They studied the effect of adding a different percentage of lime, cement and bitumen to the soil (Arora, 2003; Bhavsar, 2014; Djouimaa et al., 2018). Abdulla and Majeed (2014) studied the physical properties of expansive soil by using different percent of MWP from a different area, the result displays a decrease in the Atterberg limit. Duong and $\mathrm{Nu}$ (2020) investigate some geotechnical properties of cementadmixed soil using a different type of rice husk ash, the result of this study show increase of unconfined compressive strength and a decrease in plastic limit.

Luan et al. (2021) studied the consolidation properties of soft soil. The results indicated a decreased coefficient of consolidation of soft soil with increases in compression pressure. The soils in some areas of the governorate of Erbil are essentially expansive. Soil treatment is a technique used to improve soil engineering properties and is widely used to improve soil structures. Recognizing the importance of taking up systematic research on the swelling characteristics of Erbil soils in Bastora (BA) and Erbil Airport (EA) area by adding a different type of MWP of Penjwen (PN), Said Sadiq (SS) and Pirmam $(\mathrm{PM})$ in a different percent mixed with the natural soil to treat or minimize swelling potential of the expansive soils of Erbil, geotechnical experiments were carried out on treated soils by improvement engineering characteristics of soils to bring about the needed enhancements the expansive soil and protect the environment from the pollution of the MWP, this study has been taken up.

\section{Study Area}

The study area is located in the northeastern part of Iraq. Two locations within the Erbil were chosen for the present study (Fig. 1). BA area; near Green Land City about $30 \mathrm{~km}$ to the northeast of Erbil, (Lat.

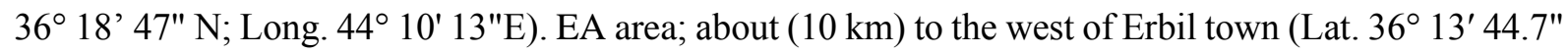
N; Long. 43 57' 36.14"E. The BA located within the Low Folded Zone; the region was distinguished by the soil profile as a result of the weathering of the rocks. The second section at EA is located also within the Foot Hill Zone. The area is covered by thick quaternary sediments (Jassim and Goff, 2006).

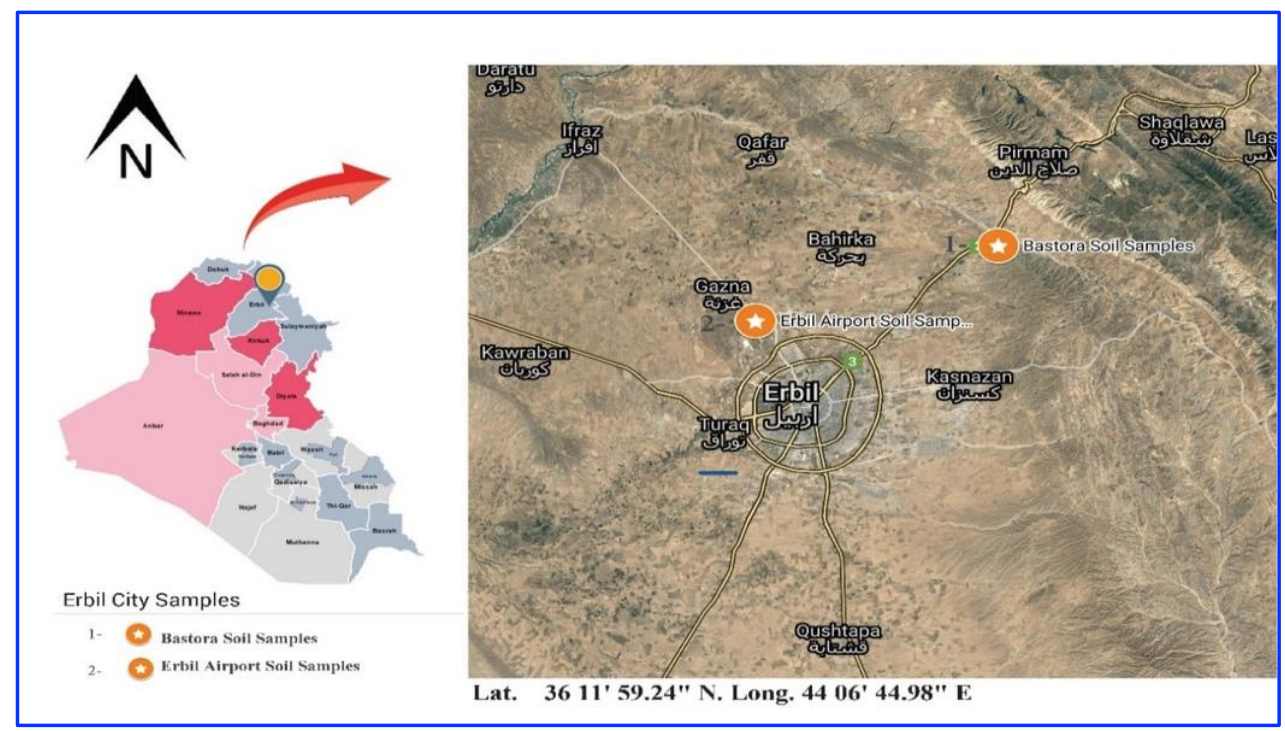

Fig.1. Location map of soil samples of the study area 


\section{Materials and Methods}

\subsection{Field Work}

The fieldwork was carried out in the area around Erbil to study soil behavior and to select the appropriate locations for this study.

\subsection{Sampling}

Soil samples were taken from two separate areas around the city of Erbil, the BA and the EA area. According to unified soil classification system, the BA natural soil is high plasticity clayey soil and Airport natural soil is low plasticity clayey soil

\subsection{Preparation of Samples}

\subsubsection{Proctor compaction test}

For the estimation of the maximum dry density and the optimum moisture content (OMC), the standard proctor test was followed in accordance with ASTMD, 698, 1998

\subsubsection{Direct shear test}

Is conducted in compliance with ASTM D 3080, 1998. One of the simplest laboratory instruments used to calculate soil shear strength is the shear box. For the determination of the shear strength of the swelling soil in the current analysis. The instruments supplied by Farrance (1995) can handle specimen sizes of $60 \mathrm{~mm} * 60 \mathrm{~mm}$. 20 sample soil specimen is put in a separate mold and shearing forces are applied until one portion of the sample slides relative to the other portion. On multiple specimens at various loads common to the shearing force, the test is repeated. The angle of friction and cohesion of the soil is determined by the test (Rahn, 1986).

\subsubsection{Consolidation Test}

The test is conducted in accordance with ASTM D 2435, 1996 and a series of conventional consolidation tests have been performed on compacted soil specimens. Consolidation was investigated by a single dimensional compression test. An odometer was used to perform the measurement. The experiments were carried out on BA and EA natural soils, combined with various percentages of MWP of different areas PN, SS and PM. Soil samples are placed inside a metal ring in this experiment, with two porous stones, one at the top of the sample and the other at the bottom. Usually, samples are $50 \mathrm{~mm}$ in diameter and $20 \mathrm{~mm}$ thick (B.S.1377, 1969).

\section{Results}

\subsection{Proctor Compaction Test}

The test is done in compacted soil at various water contents in a proctor mold. The resulting soil was compacted at various water contents in a proctor mold for each soil of BA and EA areas. without the addition of MWP to obtain the compaction curves. This is used to establish relationships between the dry densities and water content to find OMC. The maximum OMC of BA natural soil is $22.5 \%$ (Fig. 2a) and EA natural soil is $21 \%$ (Fig. 2b). 

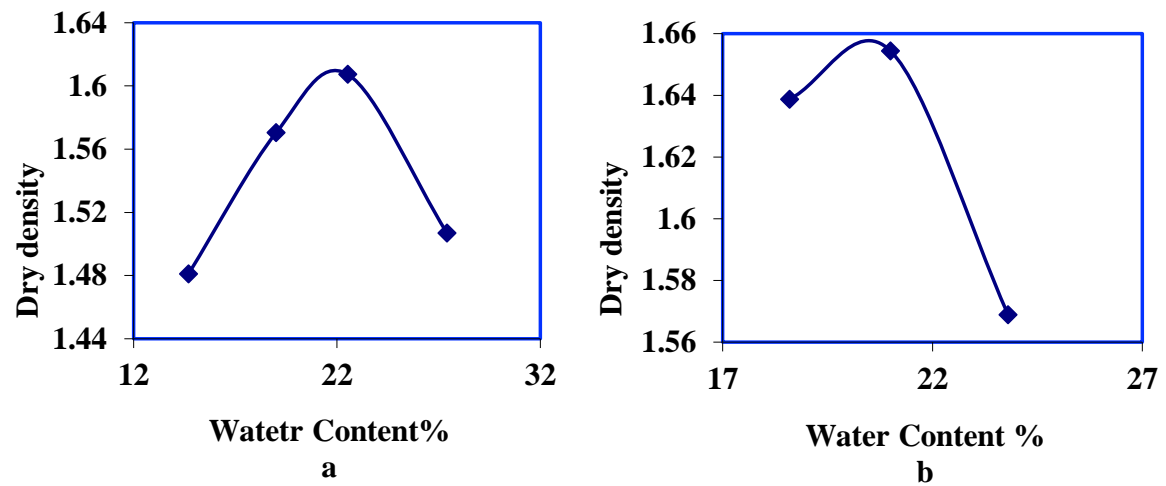

Fig. 2. Relation between water content $\%$ and dry density; a-BA natural soil b- EA natural soil

\subsection{Direct Shear Strength}

The internal resistance per unit area that the soil mass can provide for a long time to resist failure and slide within any plane is the shear strength of the soil mass (Das, 2011). In order to obtain the shear strength parameters for swelling in BA and EA soil, three separate types of MWP were used in three distinct percent, $10 \%, 20 \%$ and 30\% respectively, considering that the objective of the present investigation was to assess the efficacy MWP in the shear strength parameters of natural or treated soil Cohesion $(\mathrm{C})$ and Friction angle $((\Phi))$. The Cohesion $(\mathrm{C})$ of BA natural soil $(\mathrm{CH})$ is $56 \mathrm{KPa}$ and Friction angle $19^{\circ}$ (Fig. 3 and Table 1). For EA natural soil cohesion is (CL) $60 \mathrm{KPa}$ and Friction angle $20^{\circ}$ (Fig. 4 and Table 2).

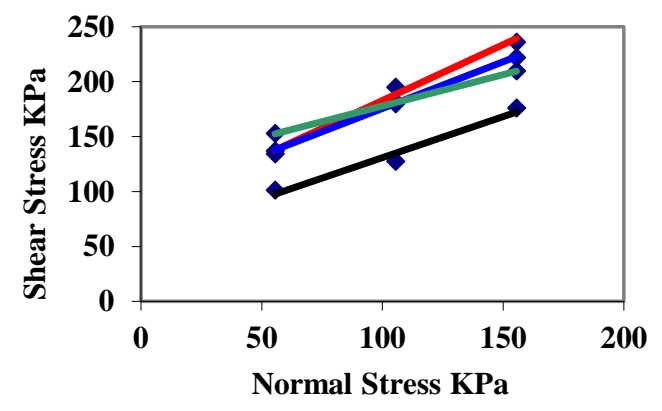

a

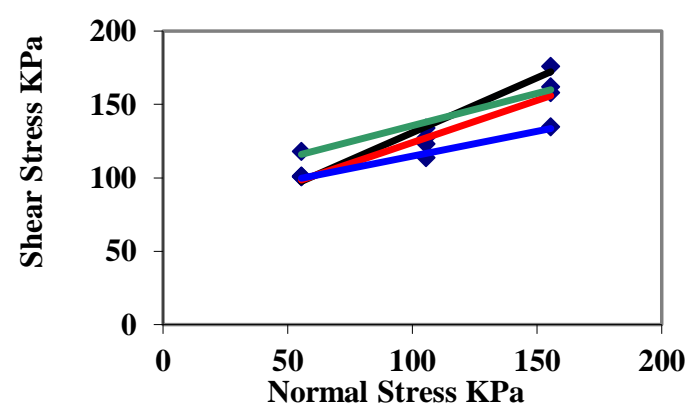

b

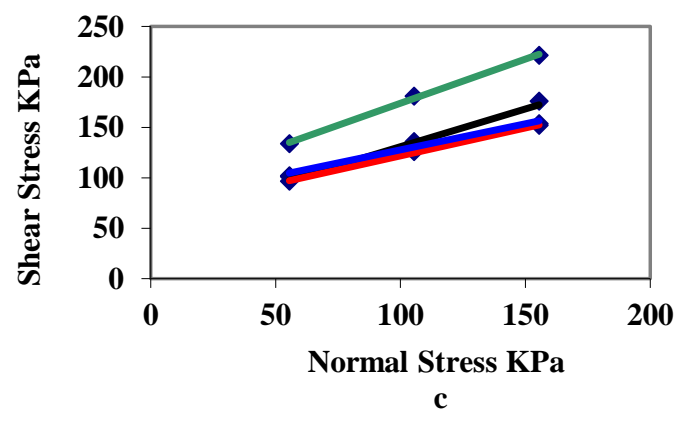

natural soil $\longrightarrow \mathbf{1 0 \%}$ marble waste $\longrightarrow 20 \%$ marble waste $-30 \%$ marble waste

Fig. 3. Relation between normal stress and shear stress of BA soil 
Table 1. Cohesion $(C)$ and Friction angle $(\Phi)$ of natural and treated BA soils by addition of MWP

\begin{tabular}{|c|c|c|c|c|}
\hline \multirow[t]{3}{*}{ Position } & & \multicolumn{3}{|c|}{ Cohesion (C) KPa } \\
\hline & \multirow[t]{2}{*}{ Natural } & \multicolumn{3}{|c|}{ Natural soil with adding marble waste powder } \\
\hline & & $10 \%$ & $20 \%$ & $30 \%$ \\
\hline BA natural soil & 56 & & & \\
\hline $\mathrm{PN}$ & & 80 & 95 & 120 \\
\hline SS & & 70 & 80 & 92 \\
\hline $\mathrm{PM}$ & & 66 & 75 & 85 \\
\hline \multirow[t]{3}{*}{ Position } & & \multicolumn{3}{|c|}{ Friction angle $(\Phi)$} \\
\hline & Natural & \multicolumn{3}{|c|}{ Natural soil with adding marble waste powder } \\
\hline & & $10 \%$ & $20 \%$ & $30 \%$ \\
\hline BA natural soil & $19^{\circ}$ & & & \\
\hline $\mathrm{PN}$ & & $19^{\circ}$ & $23^{\circ}$ & $25^{\circ}$ \\
\hline SS & & $19^{\circ}$ & $25^{\circ}$ & $23^{\circ}$ \\
\hline $\mathrm{PM}$ & & $21^{\circ}$ & $22^{\circ}$ & $28^{\circ}$ \\
\hline
\end{tabular}
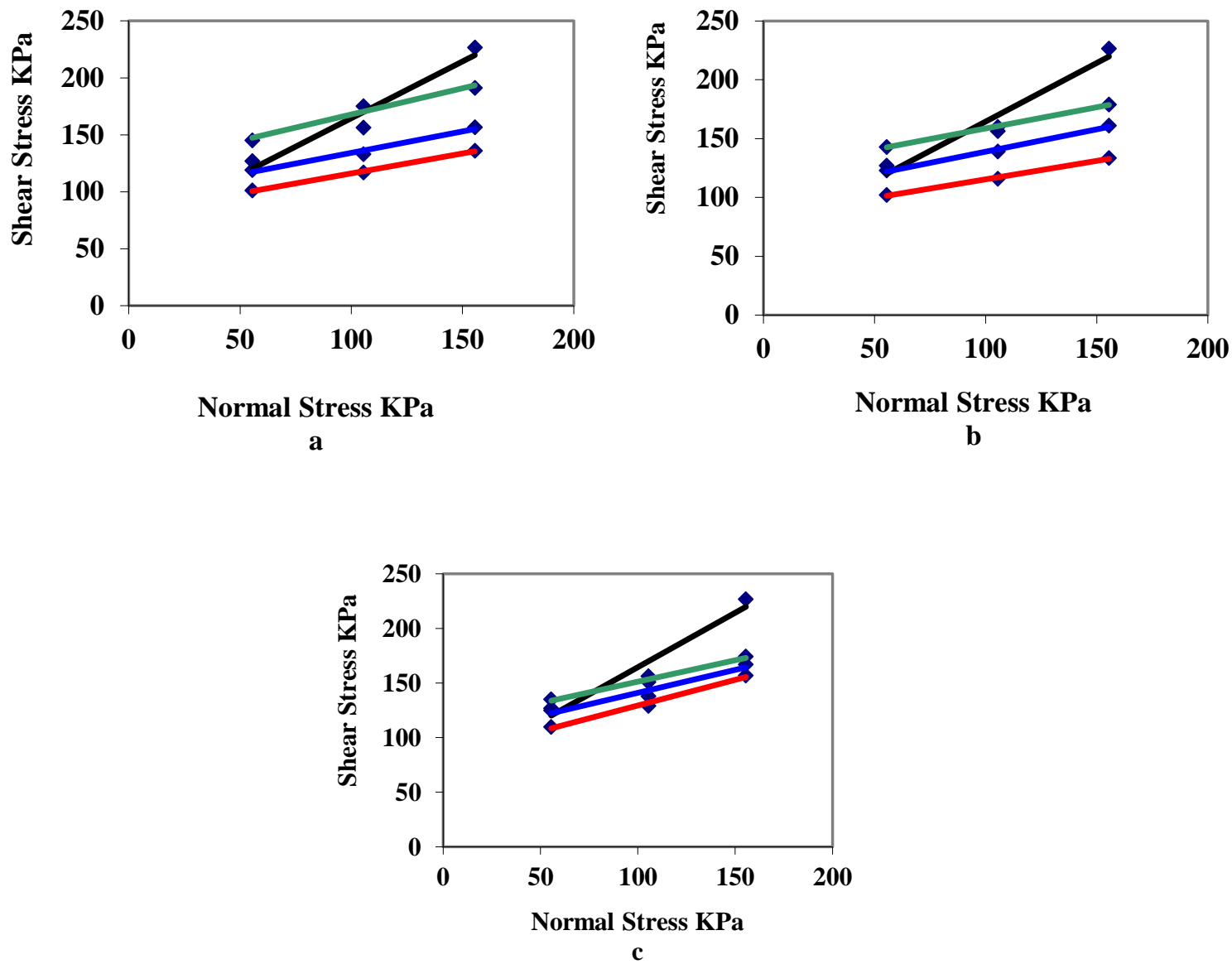

$\longrightarrow$ natural soil $\longrightarrow 10 \%$ marble waste $\longrightarrow 20 \%$ marble waste $\longrightarrow 30 \%$ natural soil

Fig. 4. Relation between normal stress and shear stress of EA soil with adding MWP of a. PN b. SS c. PM 
Table 2. Cohesion $(C)$ and friction angle $(\Phi)$ of natural and treated EA soil by addition of MWP

\begin{tabular}{|c|c|c|c|c|}
\hline \multirow[t]{3}{*}{ Position } & \multicolumn{4}{|c|}{ Cohesion (C) KPa } \\
\hline & \multirow[t]{2}{*}{ Natural } & \multicolumn{3}{|c|}{ Natural soil with adding marble waste powder } \\
\hline & & $10 \%$ & $20 \%$ & $30 \%$ \\
\hline EA natural soil & 60 & & & \\
\hline $\mathrm{PN}$ & & 80 & 99 & 120 \\
\hline SS & & 86 & 105 & 125 \\
\hline PM & & 85 & 100 & 110 \\
\hline \multirow[t]{3}{*}{ Position } & \multicolumn{4}{|c|}{ Friction angle $(\Phi)$} \\
\hline & \multirow[t]{2}{*}{ Natural } & \multicolumn{3}{|c|}{ Natural soil with adding marble waste powder } \\
\hline & & $10 \%$ & $20 \%$ & $30 \%$ \\
\hline EA natural soil & $20^{\circ}$ & & & \\
\hline $\mathrm{PN}$ & & $26^{\circ}$ & $25^{\circ}$ & $26^{\circ}$ \\
\hline SS & & $28^{\circ}$ & $30^{\circ}$ & $32^{\circ}$ \\
\hline PM & & $25^{\circ}$ & $27^{\circ}$ & $30^{\circ}$ \\
\hline
\end{tabular}

\subsection{Consolidation}

Consolidation is decreasing in the volume of saturated soil because of displacement of some of the water inside the void under influence the external stress (Al-Ashoo, 1991). The slope of the linear portion of the e-log plot is the compression index $(\mathrm{Cc})$ and is dimensionless. The current research reveals that the void ratio in BA natural soil is about 1.809, the Compression index is 0.26 , and Swelling index 0.036 (Fig. 5a and Table 3). In EA natural soils, the void ratio is 1.25 , the Compression index is 0.02 , and the Swelling index 0.0055 in the ((Fig. 5b and Table 4).
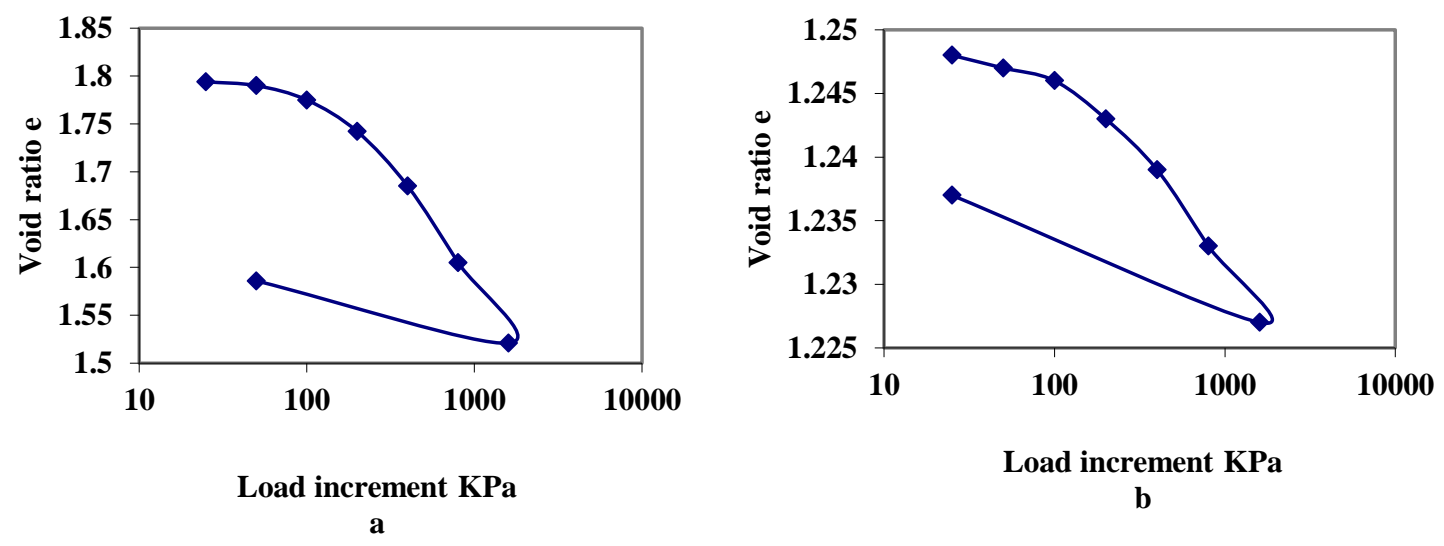

Fig. 5. Relation between load increment and void ratio; a- BA natural soil; b- EA natural soil

It was seen that Compression index $\mathrm{Cc}$ has decreased with marble waste powder increasing for all specimens (Fig.6 and Fig.7). For BA soil, the maximum reduction of $\mathrm{Cc}$ is 0.01 by adding $30 \%$ MWP of PM and for EA soil (0.0066) also by addition 30\% MWP of SS. Similarly, with increasing the percent of MWP, the void ratios of specimens have decreased. The maximum reduction of BA soils is 1.06 and EA soils 0.968 by adding 30\% MWP of PM and SS area. Consolidation settlement of soils is fewer when soil voids decreased. The findings show that the expansion index of specimens decreases when 
the amount of added marble powder increases. Therefore, the maximum swelling index reduces for BA soil to 0.0027 by adding $30 \%$ MWP of SS and PM. For Airport soils is 0.0011 by adding $30 \%$ MWP of $\mathrm{PN}$ and PM.

Table 3. Void ratio (e), Compression index $\left(\mathrm{C}_{\mathrm{C}}\right)$, and Swelling index $\left(\mathrm{C}_{\mathrm{S}}\right)$ of BA natural and treated soils by addition of MWP

\begin{tabular}{|c|c|c|c|c|}
\hline \multirow[t]{3}{*}{ Position } & \multicolumn{3}{|c|}{ Void ratio (e) } & \\
\hline & \multirow[t]{2}{*}{ Natural } & \multicolumn{3}{|c|}{ Natural soil with adding marble waste powder } \\
\hline & & $10 \%$ & $20 \%$ & $30 \%$ \\
\hline BA natural soil & 1.809 & & & \\
\hline PN & & 1.67 & 1.47 & 1.32 \\
\hline SS & & 1.65 & 1.58 & 1.34 \\
\hline PM & & 1.62 & 1.43 & 1.06 \\
\hline \multirow[t]{3}{*}{ Position } & \multicolumn{4}{|c|}{ Compression index $\left(\mathrm{C}_{\mathrm{C}}\right)$} \\
\hline & Natural & \multicolumn{3}{|c|}{ Natural soil with adding marble waste powder } \\
\hline & & $10 \%$ & $20 \%$ & $30 \%$ \\
\hline BA natural soil & 0.26 & & & \\
\hline PN & & 0.02 & 0.018 & 0.016 \\
\hline SS & & 0.18 & 0.023 & 0.016 \\
\hline $\mathrm{PM}$ & & 0.02 & 0.016 & 0.01 \\
\hline \multirow[t]{3}{*}{ Position } & \multicolumn{4}{|c|}{ Swelling index $\left(\mathrm{C}_{\mathrm{s}}\right)$} \\
\hline & Natural & \multicolumn{3}{|c|}{ Natural soil with adding marble waste powder } \\
\hline & & $10 \%$ & $20 \%$ & $30 \%$ \\
\hline BA natural soil & 0.036 & & & \\
\hline PN & & 0.0055 & 0.0038 & 0.003 \\
\hline SS & & 0.022 & 0.0044 & 0.0027 \\
\hline PM & & 0.0042 & 0.0033 & 0.0027 \\
\hline
\end{tabular}

Table 4. Void ratio (e), Compression index $\left(\mathrm{C}_{\mathrm{c}}\right)$, and Swelling index $\left(\mathrm{C}_{\mathrm{S}}\right)$ of EA natural and treated soil by addition of MWP

\begin{tabular}{|c|c|c|c|c|}
\hline \multirow[t]{3}{*}{ Position } & \multicolumn{3}{|c|}{ Void ratio (e) } & \\
\hline & \multirow[t]{2}{*}{ Natural } & \multicolumn{3}{|c|}{ Natural soil with adding marble waste powder } \\
\hline & & $10 \%$ & $20 \%$ & $30 \%$ \\
\hline EA natural soil & 1.25 & & & \\
\hline $\mathrm{PN}$ & & 1.14 & 1.11 & 1.004 \\
\hline SS & & 1.18 & 1.15 & 0.968 \\
\hline PM & & 1.1 & 1.07 & 0.978 \\
\hline \multirow[t]{2}{*}{ Position } & \multicolumn{4}{|c|}{ Compression index $\left(\mathrm{C}_{\mathrm{C}}\right)$} \\
\hline & Natural & \multicolumn{3}{|c|}{ Natural soil with adding marble waste powder } \\
\hline & & $10 \%$ & $20 \%$ & $30 \%$ \\
\hline EA natural soil & 0.02 & & & \\
\hline PN & & 0.016 & 0.013 & 0.012 \\
\hline SS & & 0.013 & 0.01 & 0.0066 \\
\hline PM & & 0.016 & 0.013 & 0.01 \\
\hline \multirow[t]{3}{*}{ Position } & \multicolumn{4}{|c|}{ Swelling index (Cs) } \\
\hline & Natural & \multicolumn{3}{|c|}{ Natural soil with adding marble waste powder } \\
\hline & & $10 \%$ & $20 \%$ & $30 \%$ \\
\hline EA natural soil & 0.0055 & & & \\
\hline PN & & 0.0033 & 0.0016 & 0.0011 \\
\hline SS & & 0.0038 & 0.0022 & 0.0016 \\
\hline PM & & 0.0038 & 0.0016 & 0.0011 \\
\hline
\end{tabular}



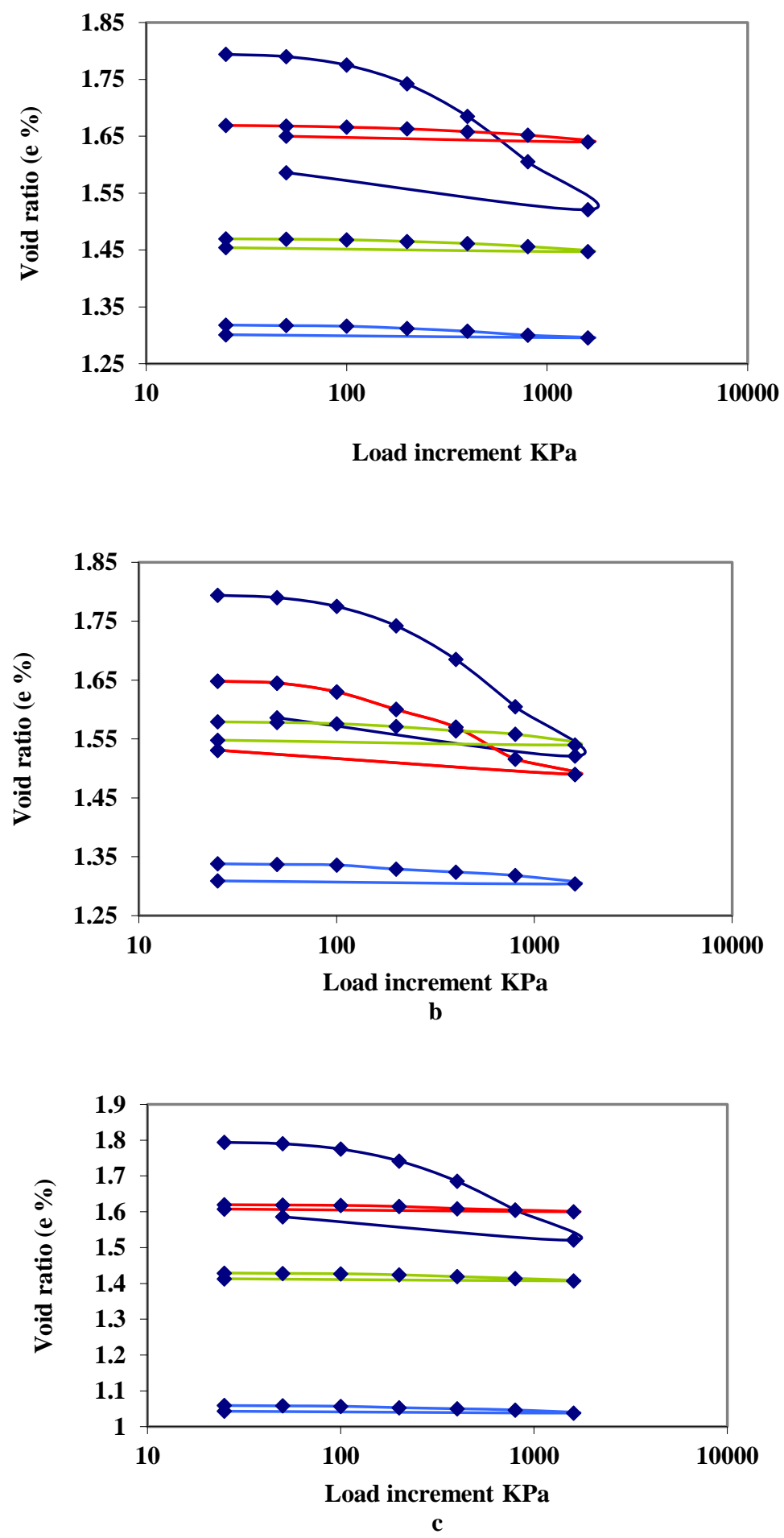

$\multimap$ natural $\prec 10 \%$ marbl $\prec 20 \%$ marbl $\prec 30 \%$ marbl

Fig. 6. Relation between load increment and void ratio of BA soils with adding MWP of a. PNb. SS C. PM 

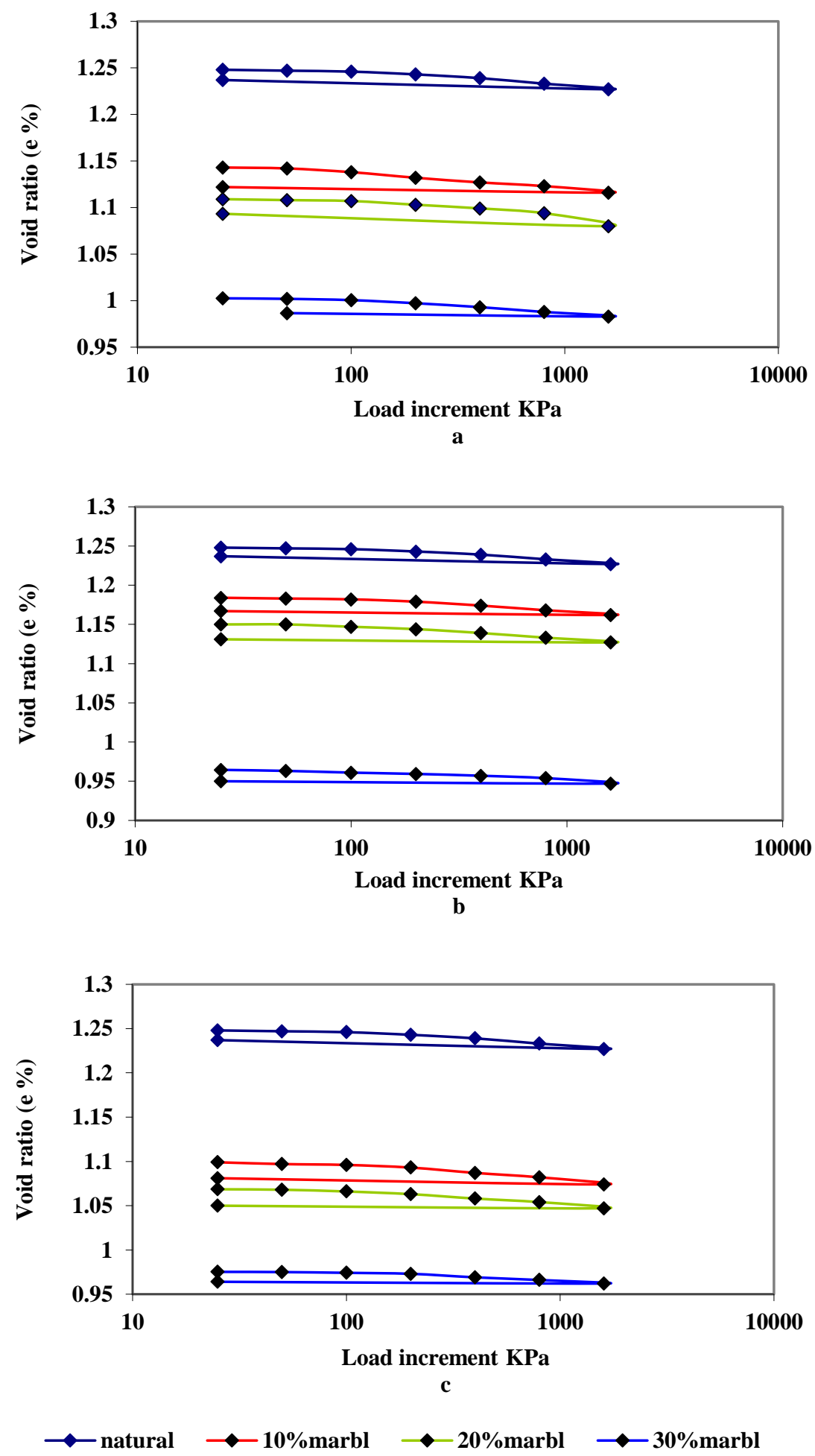

Fig. 7. Relation between load increment and void ratio of EA soils with adding MWP of a. PN b. SS C. PM

\section{Discussion}

The MWP of PN, SS and PM (10\%, 20\%, 30\%)) have been added to the expansive natural soils of $\mathrm{BA}$ and EA, the cohesion of BA and EA soils has increased as the stabilizer percentage increases. Pastor et al. (2019) found the same results. The maximum increase of cohesion in BA soil is $64 \mathrm{KPa}$ (from 56 
$\mathrm{KPa}$ to $120 \mathrm{KPa}$ ) with MWP of PN and the maximum increase of cohesion in EA soil is $65 \mathrm{KPa}$ (from $60 \mathrm{KPa}$ to $125 \mathrm{KPA}$ ) with MWP of SS. These indicate that when stabilizer percentages increase, the cohesion is more affected by adding MWP. The maximum increasing of friction angle $(\Phi)$ in BA soil is $9^{\circ}$ (from $19^{\circ}$ to $28^{\circ}$ ) by adding $30 \%$ of MWP of PM, and the maximum increasing friction angle $(\Phi)$ of EA soil is $12^{\circ}$ (from $20^{\circ}$ to $32^{\circ}$ ) by adding $30 \%$ of the MWP of SS. The Cohesion and friction angle are more affected by addition of the MWP with the soils, as shown in Tables 1,2. These also indicate that MWP stabilized the shear strength parameters. When the amount of the added MWP increases the void ratio and consolidation parameters are decreases. The maximum reduction void ratios of BA soils are 0.749 (from1.809 to 1.06) and EA soils 0.282 (from 1.25 to 0.968 ) by adding $30 \%$ of the MWP of PM and SS. The maximum reduction of Compression index Cc for BA soil is 0.25 (from 0.26 to 0.01 ) by adding $30 \%$ of the MWP of PM and for EA soil is 0.0134 (from 0.02 to 0.0066 ) by adding $30 \%$ of the MWP of SS. The maximum swelling index reduces for BA soil is 0.0333 (from 0.036 to 0.0027 ) by adding $30 \%$ MWP of SS and PM. For EA soils is 0.0044 (from 0.0055 to 0.0011 ) by addition $30 \%$ MWP of PM. This case shows that MWP can be used at stabilization of swelling soils. Depending on the geotechnical analysis for swelling tests, it is determined that the swelling of BA soils are more than the EA soils. In order to stabilized of this case, the MWP of three different areas (PN, SS and PM), with a different percent are added to the soils of both studied areas. In a result the MWP of PN is more affective to avoid the swelling cases, MWP of PM is least affective due to of higher content of carbonate minerals and its sedimentary origin (i.e not metamorphosed carbonate rocks).

\section{Conclusions}

The suitability of marble waste powder as a stabilizing agent for the expansive soil's swelling potential has been investigated in the present study. MWP in three different areas (PN, SS, and PM) with three different percent $(10 \%, 20 \%$ and $30 \%)$ was added to the two swelling soil samples of BA and EA areas. Detailed geotechnical experiments were carried out on each specimen. According to test results, the OWC (Optimum water content) by compaction test of BA area is $22.5 \%$ and the OWC of EA area is $21 \%$. By addition of $10 \%, 20 \%$ and $30 \%$ of the MWP of PN, SS, and PM to the natural soil of BA and EA area led to decrease in the Compression index (Cc) and Swelling index (Cs). While increase the Cohesion $(C)$ of shear strength and friction angle $(\Phi)$. Depending on the swelling index tests, it is concluded that the swelling of BA soil is more than the EA soil. MWP can be used to avoid the swelling problems. The analysis showed that the MWP of PN is more affective to avoid the swelling cases its metamorphosed origin, but MWP of PM is least affective because of higher content of carbonate minerals and its sedimentary origin.

\section{Acknowledgements}

The authors would like to thank the Department of Geology, University of Salahaddin. The authors are very grateful to the Editor in Chief Prof. Dr. Salih M. Awadh, the Secretary of Journal Mr. Samir R. Hijab and the Technical Editors for their great efforts and valuable comments.

\section{References}

Abdulla, R. S, Majeed, N.N., 2014. Some physical properties treatment of expansive soil using marble waste powder. International Journal of Engineering Research \& Technology (IJERT), 2278-0181 (3), 591-600

Al-Asho, M.O., 1991. Principles of soil mechanics. Dar Al-Kutib. Mosul University (in Arabic). 574 pp.

Arora, D. K. R, 2003. Soil Mechanics and Foundation Engineering, 6th edition, 170S-B, Nai Sarak, Delhi-11OOO6, 903pp.

ASTM D 2435,1996. Standard Test Method for One-Dimensional Consolidation Properties of Soils. Annual Book of ASTM Standards. Vol. 04.08. ASTM International. West Conshohocken, 1-10 pp. 
ASTM D 3080, 1998. Standard Test Method for Direct Shear Test of Soils Under Consolidated Drained Conditions. Annual Book of ASTM Standards. Vol. 04.08. ASTM International. West Conshohocken. PA. $1-6 \mathrm{pp}$

ASTM D 698, 1998. Standard Test Method for Laboratory Compaction Characteristics of Soil, Annual Book of ASTM Standards, 04.08, 77-84.

Bhavsar, S. N, Patel, A. J, 2014. Analysis of clayey soil using waste material. International Journal Innovative Research in Science Technology, 1(6),125-130.

British Standard Institution (B.S.), 1969. Method of test of soils for civil engineering purpose (BS 1377 part :2), London by mixing cement and silica fume. Applied Clay Science,132-133, 675- 684.

Chen, F.H, 1988. Foundation on expansive soils', Elsevier, Amsterdam. 463 pp.

Ciancio, D., Beckett, C.T. S., Carraro, J. A. H., 2013, Optimum lime content identification for limestabilised1rammed earth, Construction and Building Materials, 53, 59-65.

Das, B. M., 2011, Principles of Foundation Engineering. 7th edition. Cengage Learning. 794 pp.

Duong, N. T., Nu, N. T., 2020. Effect of different types of rice husk ash on some geotechnical properties of cementadmixed soil. Iraqi Geological Journal, 53 (2C), 1-12.

Farrance, W., 1995, Material equipment, 14th edition. Eng. Ltd., Slough, England. 450 pp.

Goodarzi, A. R., Akbari, H. R., Salimi, M., 2016. Enhanced stabilization of highly expansive clays by mixing cement and silica fume. Applied Clay Science, 132, 675-684.

Jassim, S.Z., and Goff, J. C., 2006. Geology of Iraq. Dolin, Prague and Moravian Museum, Brno, Czech Republic. $341 \mathrm{pp}$.

Pastor, J. L., Tomás, R., Cano, M., Riquelme, A., Gutiérrez, E., 2019. Evaluation of the improvement effect of limestone powder waste in the stabilization of swelling clayey soil. Sustainability, 11(3), 679.

Luan, V. N., Nu, N. T., Toan, D., M., 2021. Consolidation properties of Ho Chi Minh City Soil, Vietnam. Iraqi Geological Journal, 54 (1A), 1-10.

Mishra, A. K., Dhawan S., and Rao, S.M., 2008, Analysis of swelling and shrinkage behavior of compacted clays. Geotechnical and Geological Engineering, 26 (3), 289-298.

Nelson, J. D., Miller, D. J., 1992. Expansive Soils, Problems and Practice in Foundation and Pavement Engineering, John Wiley and Sons Inc., New York.

Rahn, P., H., 1986. Engineering Geology, An Enviromental Approach, Elsevier Science Publishing Co., Inc. 585 pp.

Djouimaa, S., Sid, M., Hidjeb, M., 2018. Effect of liame and cement on the geotechnical properties of an expansive soil. International Review of Civil Engineering, 122.

Zumrawi, M. M., Mahjoub, A. M., Alnour, I. M., 2016. Effect of some chloride salts on swelling properties of expansive soil. University of Khartoum, Engineering Journal, 6(2), 52-58.

Zumrawi, M. M. E., Mohammed, A. E., 2019. Effects of poly vinyl acetate on characteristics of expansive soil. Journal of Materials and Engineering Structures, 6(2), 167-176. 